\title{
Deoxyribonucleic Acid Base Compositions, and Homology of "Microcyclus,"'Spirosoma, and Similar Organisms
}

\author{
JOHN M. LARKIN* AND RENEE BORRALL \\ Department of Microbiology, Louisiana State University, Baton Rouge, Louisiana 70803
}

\begin{abstract}
The nonmotile, vibrioid, curly or ring-forming bacteria were examined to assess their systematic relationships through determination of the guanine-plus-cytosine contents of their deoxyribonucleic acids and the degrees of homology among the deoxyribonucleic acids of the various genera and species. Our results verify that Runella, Flectobacillus, Spirosoma, and Ancylobacter ("Microcyclus") are separate genera. However, our results also indicate that (i) "Ancylobacter eburneus" is not a separate species but is in fact a strain of Ancylobacter aquaticus, (ii) Flectobacillus marinus should not be used to create the new genus "Cyclobacterium" and the latter name should be discarded, and (iii) "Renobacter" is very similar to Ancylobacter, but these two genera exhibit very low levels of deoxyribonucleic acid-deoxyribonucleic acid homology and should probably remain separate at least until additional information is available.
\end{abstract}

In Bergey's Manual of Determinative Bacteriology, 8th ed. (27), all nonmotile, curly or ring-forming vibrios are included in the genus "Microcyclus" Ørskov 1928. This genus is a heterogeneous collection of the following three species: "Microcyclus aquaticus" Ørskov (20) (the type species), "Microcyclus major" Gromov (8), and "Microcyclus flavus" Raj (22). Each of these species was described on the basis of a single isolate, and the major unifying characteristics of these organisms were their curved shape and lack of motility. Several investigators $(4-6,11,15)$ found that this grouping is unsatisfactory, and after additional isolates were obtained and examined, it was proposed that the three species actually represent separate genera; "Microcyclus flavus" was placed in the revived genus Spirosoma as Spirosoma linguale (15), "Microcyclus major" was transferred to the genus Flectobacillus as Flectobacillus major (15), and "Microcyclus aquaticus" remained unchanged.

In later developments within this morphological group, (i) a marine form, "Microcyclus marinus" Raj, was described (23) and then moved to the genus Flectobacillus (4) as Flectobacillus marinus, (ii) two new isolates formed the basis for the establishment of the new genus Runella (14), (iii) the new organism "Renobacter" was found (19), (iv) a new species of "Microcyclus," "Microcyclus eburneus" (10), was named, and (v) the family Spirosomaceae (12) was created to include the genera Spirosoma, Runella, and Flectobacillus and to separate these genera from the genus "Microcyclus."

Early attempts to determine the relationships among these organisms by using deoxyribonucleic acid (DNA)-DNA hybridization demonstrated that "Microcyclus aquaticus" was not related to Spirosoma sp. or to F. marinus (11). Later, on the basis of an unpublished numerical taxonomic study, it was suggested that $F$. marinus is not closely related to $F$. major and should be treated as a separate genus, "Cyclobacterium" (H. D. Raj, Abstr. Annu. Meet. Am. Soc. Microbiol. 1979, I31, p. 100). It has been suggested (24) that the affiliations among these curly organisms are uncertain and that molecular data are needed to clarify these relationships (25).

Recently, the generic name "Microcyclus" Ørskov 1928 has been found to be illegitimate because of precedence of a

* Corresponding author. fungal genus having the same name. The name Ancylobacter has been proposed as a substitute (26) and is used below.

The purpose of this investigation was to determine whether the present classification scheme, which is based primarily on morphology and physiology, is justified by similarities in the DNA compositions of the species and by the levels of DNA homology.

\section{MATERIALS AND METHODS}

Bacterial strains. Cultures were obtained from the Deutsche Sammlung von Mikroorganismen (DSM) through the kindness of D. Claus, Gottingen, Federal Republic of Germany and from private collections. The cultures of type strains obtained from the DSM included the Ørskov strain of Ancylobacter aquaticus ("Microcyclus aquaticus" strain DSM 101), the Gromov strain of F. major ("Microcyclus major" DSM 109), a $S$. linguale strain (Spirosoma strain DSM 74), "Renobacter vacuolatum" DSM 1277, and "Ancylobacter eburneus" ("Microcyclus eburneus") DSM 1106. A. aquaticus ("Microcyclus aquaticus") strain B was obtained from J. Staley, F. major strain S-1 was obtained from R. Metcalf, F. major strain 014 was obtained from H. Gude, and $F$. marinus was obtained from H. Raj. F. major strains LAH and 3, S. linguale strains SLE, EB, and 5, and Runella slithyformis strains 4 and 6 were isolated in our laboratory. All cultures were maintained at room temperature on MS agar slants (14) and were transferred biweekly. For $F$. marinus, $3.0 \% \mathrm{NaCl}$ was added to all growth media.

Extraction and purification of DNA. Cells were harvested after $48 \mathrm{~h}$ of growth at $25^{\circ} \mathrm{C}$ in MS broth and were suspended in $10 \mathrm{ml}$ of a $0.5 \mathrm{M} \mathrm{NaCl}-0.1 \mathrm{M}$ ethylenediamine-tetraacetic acid solution at $\mathrm{pH}$ 8.0. DNA was isolated primarily by the method of Marmur (17), but with the following modification. Lysozyme $(0.04 \%$ ) was added, and after $30 \mathrm{~min}$ of incubation at $37^{\circ} \mathrm{C}$ a $1 / 800$ titer of Pseudomonas aeruginosa strain LSU 1 hemolysin (supplied by A. D. Larson) was added to a final concentration of $1.0 \%(\mathrm{vol} / \mathrm{vol})$, and the preparation was incubated for an additional $1 \mathrm{~h}$. Sodium dodecyl sulfate was then added to a final concentration of $1.0 \%(\mathrm{vol} / \mathrm{vol})$, and the suspension was heated at 60 to $65^{\circ} \mathrm{C}$ until lysis occurred. The solution was cooled, and sodium perchlorate was added to a final concentration of $1.0 \mathrm{M}$. The lysate was extracted with chloroform-isoamyl alcohol (24:1), and the DNA was precipitated in $95 \%$ ethyl alcohol.

Additional purification was done by the method of Beh- 
rens et al. (3). The purified DNA was dialyzed twice against distilled deionized water and lyophilized until it was needed.

Determination of DNA base composition. Purified DNA was dissolved in $0.1 \times$ standard saline citrate (17) to an optical density at $260 \mathrm{~nm}$ of 0.4 to 0.6 . A melting profile was obtained by thermal denaturation as described by Mandel and Marmur (16), using a Gilford model 2400 spectrophotometer equipped with a Gilford model 2527 thermoprogrammer. The control DNAs, which were obtained from Sigma Chemical Co., St. Louis, Mo., were Clostridium perfringens type XII, Escherichia coli type VIII, and Micrococcus lysodeikticus DNAs.

DNA-DNA hybridization in free solution. The procedure used for DNA-DNA hybridization was that of Barksdale et al. $(2,12)$. DNA was dissolved in $0.1 \times$ standard saline citrate to a concentration of $150 \mu \mathrm{g} / \mathrm{ml}$, fragmented by 10 passages through a 26-gauge hypodermic needle, and suspended in an equal volume of $50 \%$ formamide in $12 \times$ standard saline citrate. The DNAs were melted separately and in pairs by increasing the temperature from 60 to $95^{\circ} \mathrm{C}$ at a rate of change of $1^{\circ} \mathrm{C} / \mathrm{min}$. After the absorbance leveled off, the samples were rapidly cooled to the renaturation temperature (melting temperature $-25^{\circ} \mathrm{C}$ ), and the change in absorbance was measured at $270 \mathrm{~nm}$. Levels of homology were calculated from the renaturation rates by using the equation of DeLey et al. (7). All assays were conducted at least twice (usually three times).

\section{RESULTS}

Table 1 shows the melting temperatures and the guanineplus-cytosine $(G+C)$ contents of the DNAs of all of the strains examined, as determined by us or by other workers or both. Three clusters were identified. One cluster contained the two species of Flectobacillus $(\mathrm{G}+\mathrm{C}$ content, 37 to $41 \mathrm{~mol} \%$ ), another contained the genera Runella and Spirosoma ( $\mathrm{G}+\mathrm{C}$ content, 47 to $51 \mathrm{~mol} \%)$, and the third contained "Renobacter" and the two species of Ancylobacter $(\mathrm{G}+\mathrm{C}$ content, 65 to $67 \mathrm{~mol} \%$ ). These values confirm and expand the results of previous studies $(6,11,15)$.

The results of the DNA-DNA hybridization experiments are shown in Table 2. Three clusters of interstrain and interspecies homology were detected. Cluster I consisted of the two species of pink-pigmented vibrios (Flectobacillus). The four strains of $F$. major showed levels of homology of 82 to $97 \%$, whereas the level of homology between the type strains of $F$. major and $F$. marinus was $71 \%$. Cluster II consisted of the yellow-pigmented, curly Spirosoma strains, which had interstrain levels of homology ranging from 86 to 94\%. Cluster III consisted of the two nonpigmented, ringforming Ancylobacter species, which had levels of homology of 83 to $93 \%$. "Renobacter" did not cluster with any of these groups. To the left of the $100 \%$ homology diagonal line are the levels of homology obtained between strains representing various pairs of genera; these levels ranged from 14 to $55 \%$.

Using these data, we examined the genetic relationship of each organism to every other organism. Figures 1 through 3 group the strains both on the basis of the $\mathrm{G}+\mathrm{C}$ contents of their DNAs and on the basis of their levels of DNA-DNA homology. Figure 1 shows the relationships of the $F$. major strains to the type strain of each of the other pigmented genera and to Ancylobacter. The strains of $F$. major formed a cluster, and very near this cluster was $F$. marinus, which had a level of homology of $71 \%$ and the same $\mathrm{G}+\mathrm{C}$ content in its DNA. A similar analysis for $S$. linguale (Fig. 2) showed that the three strains used for hybridization formed a single cluster that was separated from the other organisms. The two strains of $A$. aquaticus and the single strain of " $A$. eburneus" also formed a single cluster, which was separated from the other organisms (Fig. 3). "Renobacter" did not cluster with any of the other organisms when both criteria were used.

\section{DISCUSSION}

The results described above verify the basic aspects of the classification of the curly or vibrioid, nonmotile bacteria as it has been developed on morphological and physiological considerations over the last decade. It is clear that Ancylobacter, Spirosoma, Runella, and Flectobacillus are separate genera and that Ancylobacter has little in common with the other organisms. Moreover, because the type strains of $F$. major and $F$. marinus displayed a DNA-DNA homology

TABLE 1. Melting temperatures and $G+C$ contents of the DNAs of the strains examined

\begin{tabular}{|c|c|c|c|c|}
\hline Strain & $\begin{array}{l}\text { Melting temp } \\
\text { of DNA }\left({ }^{\circ} \mathrm{C}\right)\end{array}$ & $\begin{array}{l}\mathrm{G}+\mathrm{C} \text { content of } \\
\text { DNA (mol\%) }\end{array}$ & $\begin{array}{l}\text { Previously reported } \mathrm{G}+\mathrm{C} \\
\text { content of DNA }(\mathrm{mol} \%)\end{array}$ & Reference(s) \\
\hline \multicolumn{5}{|l|}{ F. major } \\
\hline DSM $109^{\mathrm{T}}\left(=\right.$ Gromov $\left.^{\mathrm{T}}\right)$ & 68.30 & 37 & 40 & 6,15 \\
\hline $\mathrm{LAH}$ & 69.70 & 40 & & \\
\hline S-1 & 69.00 & 39 & & \\
\hline 014 & 69.75 & 40 & & \\
\hline 3 & & & 40 & 15 \\
\hline F. marinus $\mathrm{Raj}^{\mathrm{T}}$ & 70.30 & 41 & 34,38 & 11,23 \\
\hline \multicolumn{5}{|l|}{ Runella slithyformis } \\
\hline $4^{\mathrm{T}}$ & 73.55 & 48 & 50 & 15 \\
\hline 6 & & & 49 & 15 \\
\hline \multicolumn{5}{|l|}{ S. linguale } \\
\hline DSM $74^{\mathrm{Ta}}$ & & & 53 & 15 \\
\hline DSM 75 & 74.55 & 50 & 51,52 & $5,6,15$ \\
\hline SLE & 74.70 & 50 & & \\
\hline EB & 75.00 & 50 & & \\
\hline \multicolumn{5}{|l|}{ A aquaticus } \\
\hline $\operatorname{DSM} 101^{\mathrm{T}}\left(=\emptyset\right.$ rskov $\left.^{\mathrm{T}}\right)$ & 82.55 & 65 & 67 & $5,6,15,23$ \\
\hline B & & & 68 & 11 \\
\hline "A. eburneus" DSM 1106 & 82.10 & 65 & & \\
\hline “Renobacter vacoulatum" DSM 1277 & 82.50 & 65 & & \\
\hline
\end{tabular}

${ }^{a}$ Neotype strain. 
TABLE 2. Levels of homology of the DNAs of the strains examined

\begin{tabular}{|c|c|c|c|c|c|c|c|c|c|c|c|c|c|c|}
\hline \multirow[b]{2}{*}{ Strain } & \multicolumn{14}{|c|}{ \% Homology with DNA from: } \\
\hline & $\begin{array}{c}F . \text { major } \\
\text { DSM } \\
109^{\mathrm{T}}\end{array}$ & $\begin{array}{c}F . \\
\text { major } \\
\text { LAH }\end{array}$ & $\begin{array}{c}F . \\
\text { major } \\
\text { S-1 }\end{array}$ & $\begin{array}{c}F . \\
\text { major } \\
014\end{array}$ & $\begin{array}{c}\text { F. mar- } \\
\text { inus } \\
\text { Raj }^{\mathrm{T}} \\
\end{array}$ & $\begin{array}{c}\text { Runella } \\
\text { slithy- } \\
\text { formis } 4^{\mathrm{T}}\end{array}$ & $\begin{array}{c}\text { S. lin- } \\
\text { guale } \\
\text { DSM 74 }\end{array}$ & $\begin{array}{c}S . \text { lin- } \\
\text { guale } \\
\text { DSM } 75\end{array}$ & $\begin{array}{l}\text { S. lin- } \\
\text { guale } \\
\text { SLE }\end{array}$ & $\begin{array}{l}\text { S. lin- } \\
\text { guale } \\
\mathrm{EB}\end{array}$ & $\begin{array}{l}\text { A. aquat- } \\
\text { icus } \\
{\text { DSM } 101^{\mathrm{T}}}^{\text {D }}\end{array}$ & $\begin{array}{c}\text { A. } \\
\text { aquat- } \\
\text { icus B }\end{array}$ & $\begin{array}{l}\text { "A. ebur- } \\
\text { neus" } \\
\text { DSM } 1106\end{array}$ & $\begin{array}{l}\text { "Renobacter } \\
\text { vacuolatum" } \\
\text { DSM } 1277\end{array}$ \\
\hline \multicolumn{15}{|l|}{ F. major } \\
\hline DSM $109^{\mathrm{T}}$ & 100 & 93 & 86 & 97 & 71 & & & & & & & & & \\
\hline LAH & & 100 & 92 & 90 & 50 & I & & & & & & & & \\
\hline S-1 & & & 100 & 82 & 40 & & & & & & & & & \\
\hline 014 & & & & 100 & 63 & & & & & & & & & \\
\hline$F . \underset{\operatorname{Raj}^{\mathrm{T}}}{\text { marinus }}$ & & & & & 100 & & & & & & & & & \\
\hline $\begin{array}{l}\text { Runella } \\
\text { slithyfor- } \\
\text { mis } 4^{\mathrm{T}}\end{array}$ & 50 & & & & 45 & 100 & & & & & & & & \\
\hline \multicolumn{15}{|l|}{ S. linguale } \\
\hline DSM $74^{\mathrm{T} a}$ & 50 & & & & & 42 & 100 & 91 & 86 & & & & & \\
\hline DSM 75 & & & & & & & & 100 & 93 & 94 & II & & & \\
\hline SLE & & & & & & & & & 100 & & & & & \\
\hline EB & & & & & & & & & & 100 & & & & \\
\hline \multicolumn{15}{|l|}{ A. aquaticus } \\
\hline DSM $101^{\mathrm{T}}$ & 54 & & & & & & 50 & & & & 100 & 91 & 83 & \\
\hline B & & & & & & & & & & & & 100 & 93 & III \\
\hline "A. ebur- & & & & & & & 14 & & & & & & 100 & \\
\hline neus" & & & & & & & & & & & & & & \\
\hline \multirow{2}{*}{\multicolumn{15}{|c|}{ "Renobacter }} \\
\hline & & & & & & & & & & & & & & \\
\hline vacuola- & & & & & & & 55 & & & & 42 & 35 & 32 & 100 \\
\hline tum" & & & & & & & & & & & & & & \\
\hline DSM 1277 & & & & & & & & & & & & & & \\
\hline
\end{tabular}

${ }^{a}$ Neotype strain.

level of $71 \%$ and were very similar in morphology and physiology, as detemined previously (4), we feel that it is best to retain $F$. marinus as a member of the genus Flectobacillus and that the creation of the new genus "Cyclobacterium" for this organism is unwarranted (Raj, Abstr. Annu.

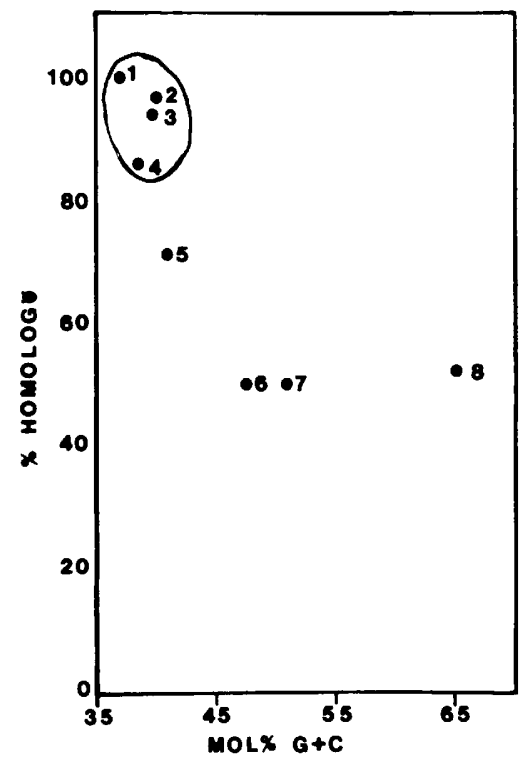

FIG. 1. Relationship of Flectobacillus strains to each other and to the type strains of species of Runella, Spirosoma, and Ancylobacter. 1, F. major Gromov ${ }^{\mathrm{T}}$ (T = type strain); $2, F$. major $014 ; 3, F$. major $\mathrm{LAH} ; 4, F$. major $\mathrm{S}-1 ; 5, F$. marinus $\mathrm{Raj}^{\mathrm{T}} ; 6$, Runella slithyformis $4^{\mathrm{T}} ; 7, S$. linguale DSM $74^{\mathrm{T}} ; 8$, A a a a aticus $\emptyset$ rskov $^{\mathrm{T}}$.
Meet. Am. Soc. Microbiol. 1979). The results of this study, when coupled with the physiological data obtained previously $(5,11,13-15)$, verify that the three pigmented genera Spirosoma, Flectobacillus, and Runella should be separated from the nonpigmented, physiologically different genus $A n$ -

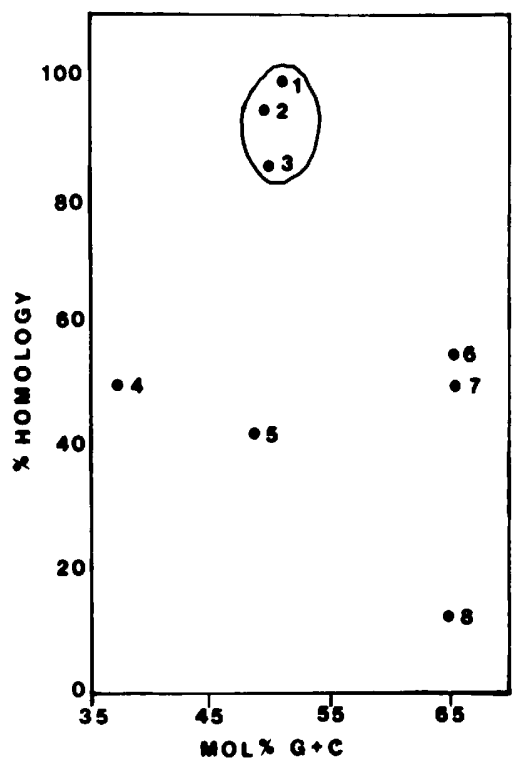

FIG. 2. Relationship of Spirosoma strains to each other and to the type strains of species of Flectobacillus, Runella, "Renobacter," and Ancylobacter. $1, S$. linguale DSM $74^{\mathrm{T}} ; 2$, S. linguale DSM $75 ; 3, S$. linguale SLE; 4, F. major Gromov'; 5, Runella slithyformis $4^{\mathrm{T}} ; 6$, "Renobacter vacuolatum" DSM 1277; 7, A. aquaticus Ørskov" ${ }^{\mathrm{T}}$; 8, “A. eburneus” DSM 1106. 


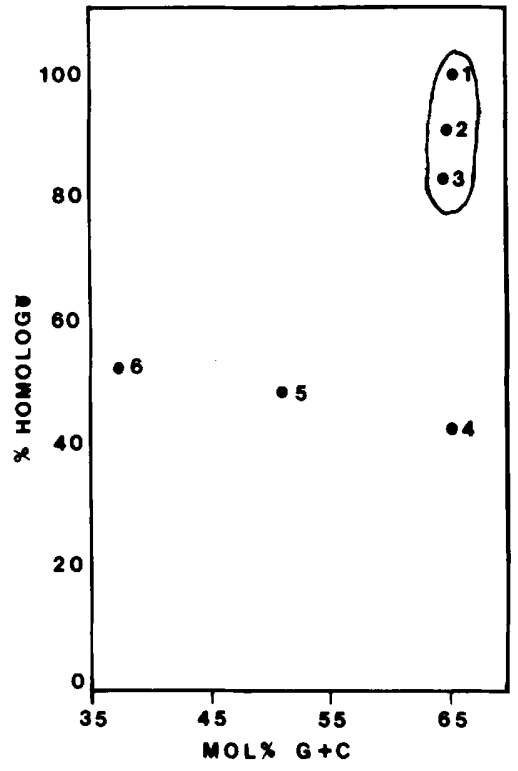

FIG. 3. Relationship of A. aquaticus strains to each other and to the type strains of species of "Renobacter," Spirosoma, and Flectobacillus. 1, A. aquaticus Ørskov' ${ }^{\mathrm{T}} ; 2$, A. aquaticus $\mathrm{B} ; 3$, , 'A. eburneus" DSM 1106; 4, "Renobacter vacuolatum" DSM 1277; 5 , $S$. linguale DSM $74^{\mathrm{T}} ; 6, F$. major Gromov ${ }^{\mathrm{T}}$.

cylobacter. To this end, we previously created the family Spirosomaceae to include only Spirosoma, Flectobacillus, and Runella.

"A. eburneus" is nearly identical to A. aquaticus in its morphology and physiology (R. Borrall, M.S. thesis, Louisiana State University, Baton Rouge, 1981). The molecular data presented here clearly show that "A. eburneus" should be considered a strain of $A$. aquaticus and not a separate species.

We were surprised that "Renobacter" did not exhibit a higher degree of DNA-DNA homology with Ancylobacter. "Renobacter"' is morphologically and physiologically similar to A. aquaticus (Borrall, M.S. thesis), and the two genera have the same $\mathrm{G}+\mathrm{C}$ content in their DNAs. Moreover, "Renobacter vacuolatum" and A. aquaticus strain B both have gas vacuoles. Because the level of hybridization of the DNAs of "Renobacter" and A. aquaticus strain B was less than the level of hybridization obtained between "Renobacter" and Spirosoma, we feel that it is best for the present to maintain "Renobacter" as a separate genus, while recognizing its probable close affinity to Ancylobacter.

It is clear that ring formation or a curly shape can no longer be considered a unifying characteristic in taxonomy. Other recently described but unrelated ring-forming or curly bacteria include the photosynthetic organisms Rhodocyclus (21), Clostridium cocleatum, and Clostridium spiroforme (9), as well as strains of Bacillus subtilis $(18,28)$ and Bacillus stearothermophilus (1).

\section{LITERATURE CITED}

1. Anagnostopoulos, G. D., and H. S. Sidhu. 1978. Helical growth of Bacillus stearothermophilus in low water activity media. Microbios Lett. 5:115-121.

2. Barksdale, L., A.-A. Laneelle, A. C. Pollice, J. Asselineau, A. Welby, and A. V. Norgard. 1977. Biological and chemical basis for the reclassification of Microbacterium flavum Orla-Jensen as Corynebacterium flavescens nom. nov. Int. J. Syst. Bacteriol. 29:222-233.

3. Behrens, H., J. Flossdorff, and H. Reichenbach. 1976. Base composition of deoxyribonucleic acid from Nannocystis exedens (Myxobacteriales). Int. J. Syst. Bacteriol. 26:561-562.

4. Borrall, R., and J. M. Larkin. 1978. Flectobacillus marinus (Raj) comb. nov., a marine bacterium previously assigned to Microcyclus. Int. J. Syst. Bacteriol. 28:341-343.

5. Claus, D. 1967. Taxonomy of some highly pleomorphic bacteria Spisy Prirodoved. Fak. Univ. J. E. Purkyne Brne 40:254-257.

6. Claus, D., J. E. Bergendahl, and A. Mandel. 1968. DNA base composition of Microcyclus species and organisms of similar morphology. Arch. Mikrobiol. 63:26-28.

7. DeLey, J., H. Cattoir, and A. Reynaerts. 1970 . The quantitative measurement of DNA hybridization from renaturation rates. Eur. J. Biochem. 12:133-142.

8. Gromov, B. V. 1963. A new bacterium of the genus Microcyclus. Dokl. Akad. Nauk. SSSR 152:733-734.

9. Kanuechi, C., T. Miyazato, T. Shinjo, and T. Mitsuoka. 1979. Taxonomic study of helically coiled, spore-forming anaerobes isolated from the intestines of humans and other animals: Clostridium cocleatum sp. nov. and Clostridium spiroforme sp. nov. Int. J. Syst. Bacteriol. 29:1-12.

10. Kono, K., and A. Ozaki. 1976. Microcyclus eburneus (ATCC 21373), p. 77. In Catalog of strains-I, American Type Culture Collection, 12th ed. American Type Culture Collection, Rockville, Md.

11. Konopka, A. E., R. L. Moore, and J. T. Staley, 1976. Taxonomy of Microcyclus and other nonmotile, ringforming bacteria. Int. J. Syst. Bacteriol. 26:505-510.

12. Laneelle, A.-A., J. Asselieau, A. Welby, A. V. Norgard, T. Imaeda, A. C. Pollice, and L. Barksdale. 1980. Biological and chemical bases for the reclassification of Brevibacterium vitarumen (Bechdel et al.) Breed (Approved Lists, 1980) as Corynebacterium vitarumen (Bechdel et al.) comb. nov. and Brevibacterium liquifaciens Okabayashi and Masuo (Approved Lists, 1980) as Corynebacterium liquifaciens (Okabayashi and Masuo) comb. nov. Int. J. Syst. Bacteriol. 30:539-546.

13. Larkin, J. M., and R. Borrall. 1978. Spirosomaceae, a new family to contain the genera Spirosoma Migula 1894, Flectobacillus Larkin et al. 1977, and Runella Larkin and Williams 1978. Int. J. Syst. Bacteriol. 28:595-596.

14. Larkin, J. M., and P. A. Williams. 1978. Runella slithyformis gen. nov., sp. nov., a curved, nonflexible, pink bacterium. Int. J. Syst. Bacteriol. 28:32-36.

15. Larkin, J. M., P. A. Williams, and R. Taylor. 1977. Taxonomy of the genus Microcyclus Ørskov 1928: reintroduction and emendation of the genus Spirosoma Migula 1894 and proposal of a new genus Flectobacillus. Int. J. Syst. Bacteriol. 27:147-156.

16. Mandel, A., and J. Marmur. 1968. Use of ultraviolet absorbance-temperature profile for determining the guanine plus cytosine content of DNA. Methods Enzymol. 12B:195-206.

17. Marmur, J. 1961. A procedure for the isolation of deoxyribonucleic acid from microorganisms. J. Mol. Biol. 3:208-218.

18. Mendelson, N. H. 1976. Helical growth of Bacillus subtilis: a new model of cell growth. Proc. Natl. Acad. Sci. U.S.A. 73:1740-1744.

19. Nikitin, D. I. 1971. A new soil microorganism-Renobacter vacuolatum gen. et sp. nov. Dokl. Akad. Nauk. SSSR 198:447.

20. Ørskov, J. 1928. Beschreibung eines neuen Mikroben, Microcyclus aquaticus, mit eigentumlicher Morphologie. Zentrabl. Bakteriol. Parasitenkd. Infektionskr. Hyg. Abt. 1 Orig. 107:180184.

21. Pfennig, N. 1978. Rhodocyclus purpureus gen. nov. and sp. nov., a ring-shaped, vitamin $B_{12}$-requiring member of the family Rhodospirillaceae. Int. J. Syst. Bacteriol. 28:283-288.

22. Raj, H. D. 1970. A new species-Microcyclus flavus. Int. J. Syst. Bacteriol. 20:61-81.

23. Raj, H. D. 1976. A new species-Microcyclus marinus. Int. J. Syst. Bacteriol. 26:528-544.

24. Raj, H. D. 1977. Microcyclus and related ring-forming bacteria. Crit. Rev. Microbiol, 5:243-269.

25. Raj, H. D. 1981. The genus Microcyclus and related bacteria, p. 
630-644. In A. P. Starr, H. Stolp, H. G. Truper, A. Ballows, and H. G. Schlegel (ed.), The prokaryotes. Springer-Verlag, New York.

26. Raj, H. D. 1983. Proposal of Microcyclus gen. nov. as a substitute for the bacterial genus Microcyclus Ørskov 1928. Int. J. Syst. Bacteriol. 33:397.
27. Staley, J. T. 1974. Genus Microcyclus, p. 214-215. In R. E. Buchanan and N. E. Gibbons (ed.), Bergey's manual of determinative bacteriology, 8th ed. The Williams \& Wilkins Co., Baltimore.

28. Tilby, A. J. 1977. Helical shape and cell wall synthesis in a bacterium. Nature (London) 266:450-452. 